Resona Jumal Ilmiah Pengabdian Masyarakat Vol. 1, No. 1 (2017) 39-45

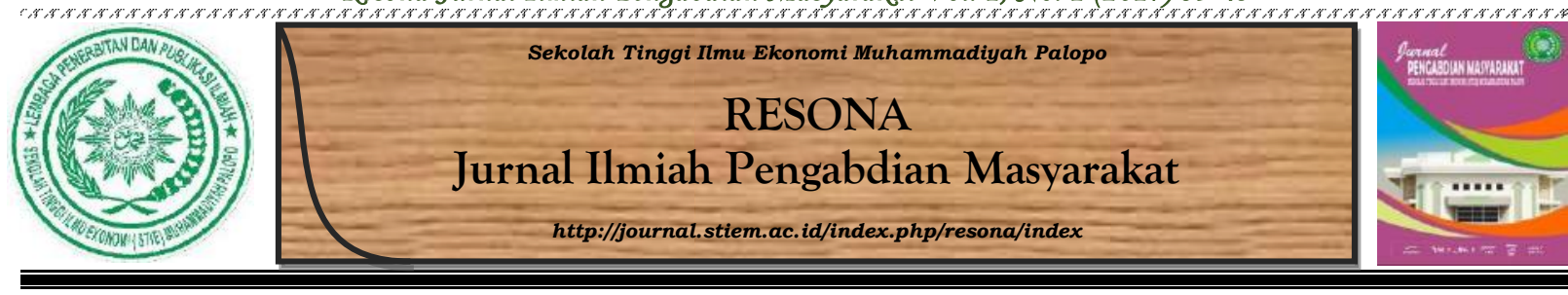

\title{
Pemberdayaan Pemuda Melalui Program Remaja Pintar Berbasis Ekonomi Kreatif Desa Lera Kecamatan Wotu Kabupaten Luwu Timur
}

\author{
Rahmad Solling Hamid ${ }^{1}$, Muhammad Ikbal ${ }^{2}$ \\ ${ }^{1,2}$ Sekolah Tinggi Ilmu Ekonomi Muhammadiyah Palopo
}

\section{INFO NASKAH \\ wiswisw, \\ Diserahkan \\ 22 Desember 2017 \\ Diterima dan disetujui \\ 26 Desember 2017

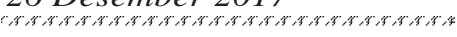

\section{Kata Kunci:}

Pemberdayaan pemuda

Program remaja pintar

Ekonomi kreatif

Entrepreneurship

Entrepreneurship

\begin{abstract}
ABSTRAK
Tujuan pengabdian ini adalah membantu menyelesaikan permasalahan yang dialami Pemuda Karang Taruna Desa Lera, dalam kaitannya dengan beberapa keterampilan usaha dan pengembangan bidang teknologi informasi internet sebagai ajang promosi atau pemasaran produk kerajinan Desa Lera. Permasalahan yang dialami pemuda karang taruna adalah rendahnya pengetahuan dan minimnya kegiatan entrepreneurship di Desa Lera, Kecamatan Wotu Kab, Luwu Timur, serta masih rendahnya kualitas Sumber Daya Manusia (SDM). Solusi yang ditawarkan dalam kegiatan ini adalah memberikan pelatihan berwirausaha, membuat kursi sofa dari limbah ban bekas, dan membuat website sebagai media pemasaran melalui internet dengan menekankan pada promosi potensi-potensi hasil kegiatan usaha kreatif yang telah dikembangkan. Tolak ukur keberhasilan kegiatan ini adalah terbentuknya kelompok atau pribadi usaha kreatif melalui seminar entrepreneurship dan pelatihan usaha kreatif yaitu warkop pemuda Desa Lera sebagai kegiatan tambahan. Selain itu, kegiatan ini juga memberikan pelatihan pembuatan kursi sofa dengan memanfaatkan limbah ban bekas; pembuatan kerupuk berbahan dasar sagu dan beras; dan meningkatkan pengetahuan masyarakat khususnya pemuda karang taruna melalui pelatihan pembuatan dan pengelolaan media pemasaran berbasis internet seperti blog dan media sosial.
\end{abstract}

\section{Pendahuluan}

Membangun desa dengan karakteristik yang berbeda bukanlah masalah yang sederhana. Membangun desa adalah membangun manusia dengan segala hak dan kewajibannya yang perlu mendapat perhatian. Salah satu kiat untuk membangun desa yaitu dengan cara menumbuhkan jiwa entrepreneurship dan kreatifitas melalui pengembangan ekonomi kreatif. Industri kreatif adalah industri yang beraskala dari pemanfaatan kreativitas, keterampilan serta

\footnotetext{
Corresponding Author:

${ }^{1}$ rahmadhamid@stiem.ac.id; +62 82347283889

2 muhikbal@stiem.ac.id; +62 81342658824
} 
bakat individu untuk menciptakan kesejahteraan dan lapangan pekerjaan dengan menghasilkan dan memberdayakan daya kreasi dan daya cipta individu tersebut (Departemen Perdagangan RI, 2009). Menurut Howkins (2001), ekonomi kreatif terdiri dari periklanan; arsitektur; seni; kerajinan; desain; fashion; film; musik; seni pertunjukkan; penerbitan; penelitian dan pengembangan $(\mathrm{R} \& \mathrm{D})$; perangkat lunak; mainan dan permainan; televisi dan radio; dan permainan video.

Desa Lera berdiri pada bulan Agustus 1992 dan termasuk dalam teritorial wilayah Kecamatan Wotu, Kabupaten Luwu Timur. Luas wilayah Desa Lera yakni 7,75 km² dengan jumlah penduduk mencapai 2.563 jiwa. Desa Lera terdiri dari 6 (enam) dusun yakni Dusun Maranindi (3 RT), Dusun Bandoa (3 RT), Dusun Sekayu (2 RT), Dusun Cendana Hijau 1 (3 RT), Dusun Cendana Hijau 2 (6 RT), dan Dusun Sejahtera (3 RT). Jumlah penduduk di Desa Lera kurang lebih berjumlah 2.563 jiwa, yang terdiri dari 1.210 berjenis kelamin laki-laki dan 1.353 berjenis kelamin perempuan.

Mata pencarian masyarakat di Desa Lera merupakan petani/pekebun sebesar 9\%, peternak sebesar 3\%, wiraswasta sebesar 9\%, PNS sebesar 1\%, karyawan sebesar 1\%, pengrajin sebesar $2 \%$ dan buruh lepas sebesar $41 \%$. Status mata pencaharian buruh dengan jumlah persentase yang tertinggi yaitu sebesar $41 \%$ sebagian besarnya didominasi adalah kelompok usia pemuda. Pada observasi awal, kami menemukan beberapa kendala yaitu organisasi Pemuda Karang Taruna yang ada di Desa Lera berjalan fakum. Menurut hasil wawancara tim dengan aparat desa utamanya dengan Kepala Desa Lera mengatakan bahwa kurangnya kegiatan yang dilakukan oleh pemuda dalam kurun beberapa tahun terakhir disebabkan sebagian pemuda di Desa Lera memilih mencari pekerjaan di luar desa atau merantau ke luar daerah. Padahal potensi alam yang dimiliki oleh Desa Lera ideal untuk dikembangkan.

Potensi pariwisata contohnya dimana potensi ini kurang dimanfaatkan dengan baik oleh Masyarakat di Desa Lera untuk menciptakan serta menumbuhkan ekonomi kreatif karena kurangnya kreativitas, inovasi, dan jiwa entrepreneurship yang dimiliki oleh masyarakat khususnya pemuda yang ada di Desa Lera. Kewirausahaan (entrepreneurship) adalah suatu proses memulai bisnis ventura, mengorganisasikan sumber-sumber daya yang dibutuhkan, memperkirakan risiko-risiko dan imbalan-imbalan yang terkait (Daft, 2007). Menurut Echdar (2013), hanya orang yang memiliki jiwa kewirausahaan yang dapat mendirikan dan mengelola usaha secara profesional.

Berdasarkan latar belakang isu di atas dan adanya rasa tanggung jawab generasi 
intelektual muda untuk membangun dan memberikan dampak positif bagi masyarakat, terutama di daerah-daerah yang perlu didukung dalam pengelolaan dan pengembangan potensi daerahnya, tim Kuliah Kerja Nyata (KKN) menentukan Desa Lera sebagai lokasi pelaksanaan program-program pengembangan Kuliah Kerja Nyata dengan alasan dan fakta-fakta observasi yang telah dilakukan oleh tim.

\section{Metode Pelaksanaan}

Pelaksanaan program terdiri dari beberapa tahapan dengan tujuan yang diharapkan. Adapun metode pendekatan program pembinaan yang dilakukan adalah sebagai berikut:

\section{Perencanaan}

a. Mempersiapkan tema dan tempat awal KKN;

b. Melakukan survei lapangan dan pencarian data terhadap tempat dan tema;

c. Melakukan koordinasi dengan pihak terkait di lokasi yang akan dijadikan objek kajian. Hal ini dilaksanakan agar sasaran kegiatan tercapai dan membawa manfaat bagi pihak yang terlibat maupun pemerintah daerah setempat;

d. Menentukan rancangan program kerja;

e. Menentukan tim dan pembagian tugas sesuai bidang studi; dan

f. Pembekalan dan gladi resik.

\section{Pelaksanaan}

Pelaksanaan program mengikuti jadwal yang telah ditetapkan oleh P3M dengan catatan proses identifikasi telah diselesaikan. Kegiatan-kegiatan pada tahapan ini difokuskan pada implementasi program dengan mempergunakan berbagai metode komunikasi (penyuluhan, pelatihan, pendampingan, pemberdayaan, dan mediasi).

\section{Evaluasi}

Tahapan ini diisi dengan berbagai kegiatan monitoring dan evaluasi berbagai program kegiatan yang telah dicanangkan. Hasil dari proses ini adalah beberapa data dan informasi perkembangan implementasi program KKN yang dilakukan secara periodik selama KKN berlangsung dan pascaprogram KKN dilaksanakan. 


\section{Rencana Keberlanjutan Program}

Program utama KKN tematik ini adalah merupakan kesempatan pertama bagi warga masyarakat kususnya pemuda karang taruna di Desa Lera untuk mempelajari dan memanfaatkan sumber daya alam yang ada di sekitarnya serta potensi sumber daya manusia yang telah dimiliki melalui beberapa pelatihan. Program pascaKKN yang rencananya akan dilakukan adalah monitoring terhadap pengembangan pariwisata tersebut. Harapannya, masyarakat dan pemuda karang taruna kususnya dapat mandiri; memiliki jiwa entrepreneurship; kreatif dalam menciptakan sesuatu; mampu meningkatkan pendapatan; dan mengembangkan kehidupan pariwisata di daerahnya tanpa bergantung dengan mahasiswa.

Selain itu, proses monitoring berfungsi sebagai pemantauan dan pemeliharaan kondisi infrastruktur, baik yang telah dibangun maupun yang telah direncanakan untuk itu. Sehingga upaya promosi pariwisata dapat berjalan dengan baik. Evaluasi secara menyeluruh dan periodik perlu jua dilakukan terhadap program yang telah dibuat dan diaplikasikan selama Kuliah Kerja Nyata untuk melihat apakah program tersebut terbukti memberikan efek positif atau sebaliknya. Jika yang didapat adalah hasil positif, maka ada baiknya jika program ini dilanjutkan oleh kelompok KKN selanjutnya. Jika sebaliknya, kelompok KKN dapat melakukan tindakan perbaikan sesuai temuan.

\section{Hasil dan Pembahasan}

Kegiatan KKN-PPM yang telah dilakukan di Desa Lera Kecamatan Wotu, Kabupaten Luwu Timur menghasilkan beberapa hal yaitu sebagai berikut:

a. Anggota Karang Taruna Desa Lera Kecamatan Wotu, Kabupaten Luwu Timur setelah diadakan pelatihan dan orientasi tentang enterpreuner banyak telah memiliki pemahaman tentang bagaimana cara berwirausaha serta berbisnis. Selain itu, mereka telah memiliki mental dan karakter yang ulet dalam berbisnis.

b. Materi pelatihan selanjutnya adalah pelatihan keterampilan usaha kreatif dan inovatif berupa pemanfaatan limbah ban bekas menjadi sofa, pembuatan kerupuk berbahan dasar sagu dan nasi untuk menambah keterampilan menarik yang bisa dipasarkan. Terbentuk kelompok/pribadi usaha kreatif dengan orientasi yang berbeda-beda jenisnya untuk menghasilkan produk yang bisa dipasarkan. Keberlangsungan kelompok/pribadi usaha kreatif tersebut sebagai sarana pemberdayaaan pemuda karang taruna yang ada di Desa Lera. Perlu dikembangkan kegiatan-kegiatan usaha kreatif alternatif lain melaui pelatihanpelatihan keterampilan. 
Materi pelatihan berikutnya adalah pelatihan dan praktik pembuatan blog sertapemanfaatan media sosial, dimana materi ini bertujuan membekali peserta pelatihan tetang bagaimana memasarkan dan mengkomunikasikan hasil-hasil atau produk usaha mereka lewat sosial media. Pelatihan dilaksanakan baik secara teori maupun praktek langsung dengan pembuatan blog dan media sosial. Hasil dari pelatihan ini, mereka secara pribadi-pribadi dan kelompok bisa membuat blog dan media sosial serta mampu mengunggah untuk mempromosikan hasil produk mereka di blog dan media sosial tersebut. Berikut ini adalah beberapa dokumentasi kegiatan program KKN-PPM yang telah dilaksanakan.

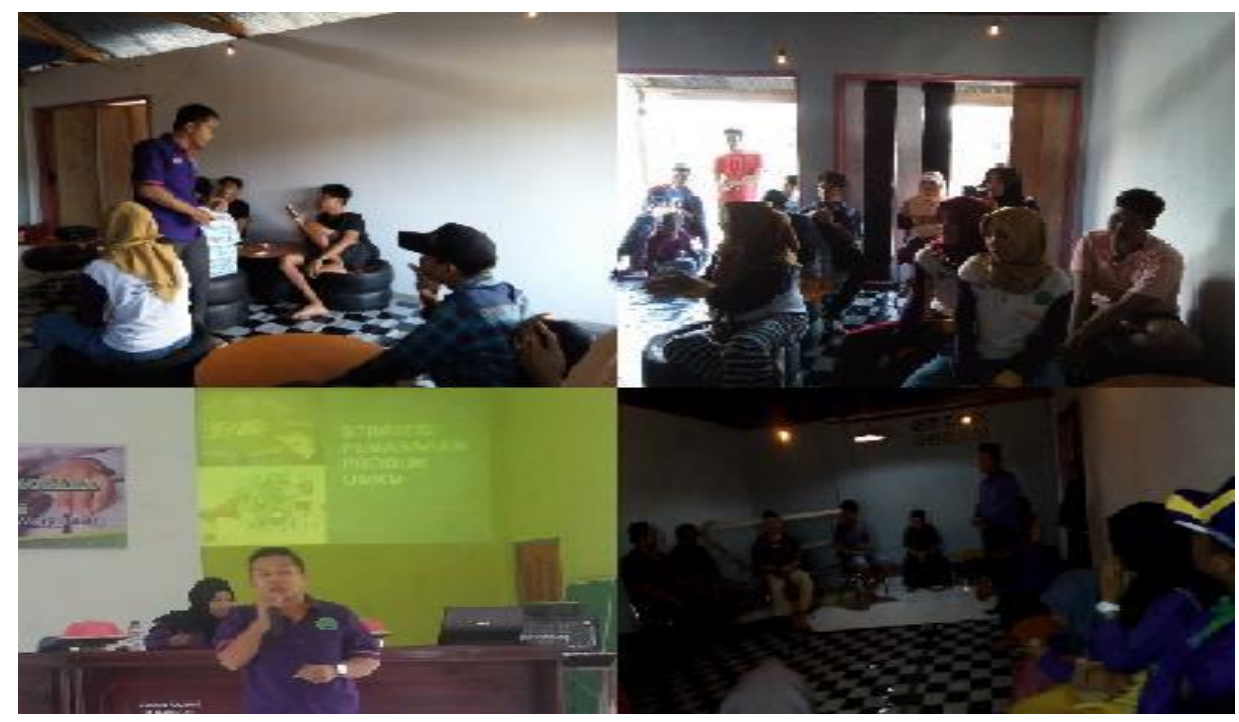

Gambar 1. Seminar/Pelatihan Entrepreneurship Berbasis Ekonomi Kreatif

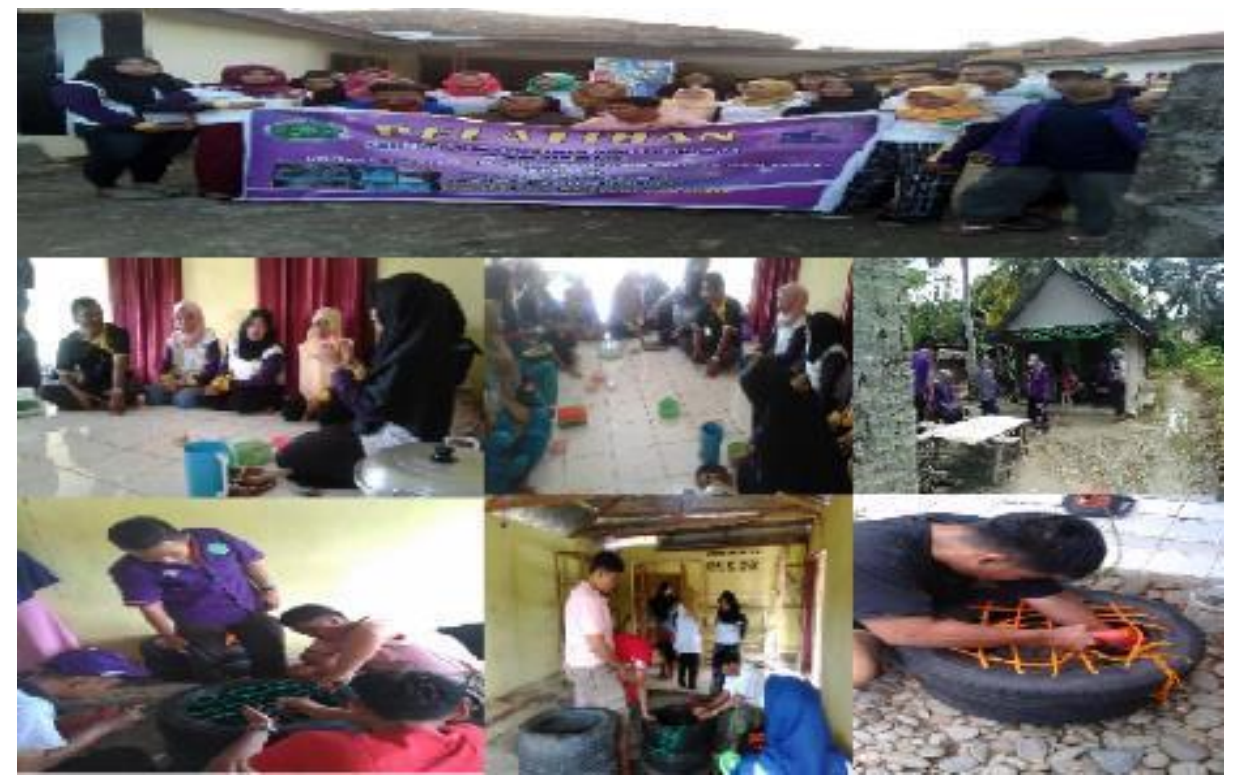

Gambar 2. Pembuatan Sofa dari Ban Bekas 


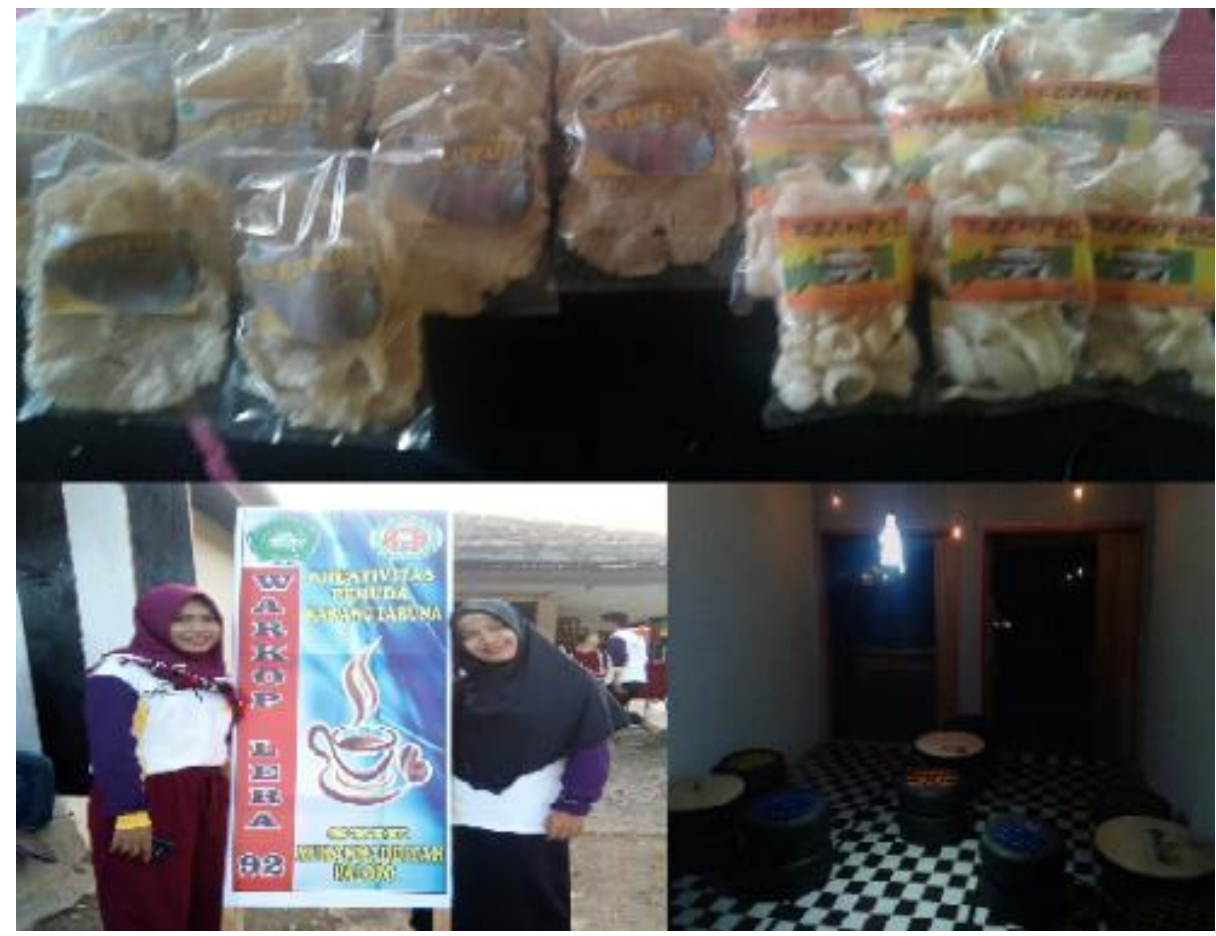

Gambar 3. Pembuatan Krupuk Berbahan Dasar Sagu dan Beras

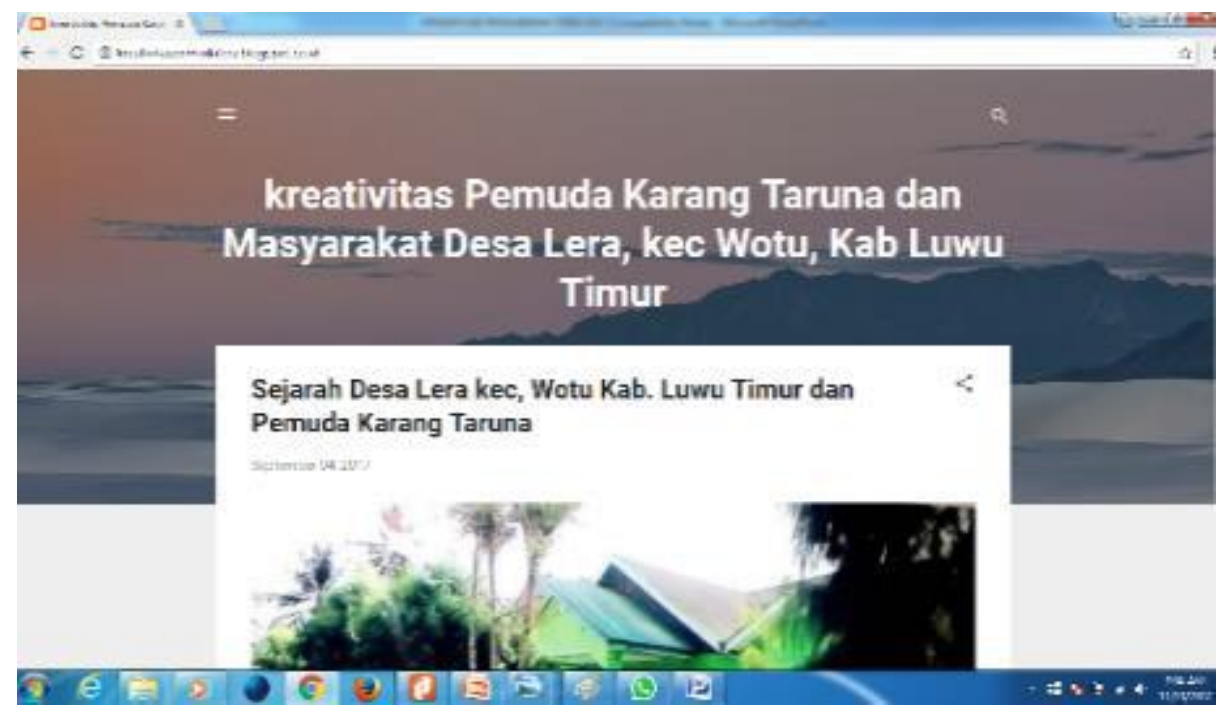

Gambar 4. Media Promosi Entrepreneur Masyarakat dan Pemuda Desa Lera

\section{Simpulan dan Saran}

Kegiatan KKN-PPM berjudul Pemberdayaan Pemuda Melalui Program Remaja Pintar Ekonomi Kreatif Desa Lera, Kecamatan Wotu, Kabupaten Luwu Timur, yang dilaksanakan mulai dari bulan Juli sampai dengan bulan Agustus 2017, dapat disimpulkan: (a) kegiatan ini disambut baik oleh masyarakat secara umum terutama pemuda Karang Taruna Desa Lera dengan bukti dukungan dan partisipasi dari segenap anggota masyarakat dan pemuda karang taruna Desa Lera; (b) terbentuknya kelompok/pribadi usaha kreatif melalui seminar 
entrepreneurship dan pelatihan usaha kreatif yaitu warkop pemuda Desa Lera sebagai kegiatan tambahan yang menghasilkan, dan pembuatan kursi sofa dengan memanfaatkan limbah ban bekas menjadi produk yang bernilai ekonomis, serta pembuatan kerupuk berbahan dasar sagu dan beras sebagai salah satu produk camilan yang memanfaatkan potensi tanaman sagu yang ada di Desa Lera; dan (c) meningkatnya pengetahuan masyarakat dan khususnya pemuda karang taruna melalui pelatihan pembuatan dan pengelolaan media pemasaran berbasis internet (blog dan media sosial).

Berakhirnya kegiatan pengabdian ini dapat direkomendasikan beberapa hal, meliputi: (a) Pengurus Karang Taruna Desa Lera, Kecamatan Wotu, Kabupaten Luwu Timur sebaiknya tetap konsisten dalam menjaga kelestarian dan kestabilan seta mengembangkan kegiatan kelompok/pribadi usaha kretif yang sudah terbentuk; (b) Local organisirs sebaiknya memberikan dukungan dan selalu memfasilitasi keberlangsungan kelompok/pribadi usaha kreatif yang ada di wilayah Desa Lera, Kecamatan Wotu, Kabupaten Luwu Timur pascapendampingan, atau setelah pendampingan berakhir; dan (c) bagi P3M STIE Muhammadiyah Palopo, kegiatan ini dibutuhkan adanya keberlanjutan program.

\section{Daftar Pustaka}

Daft, R.L. 2007. Manajemen. Edisi Keenam. Jakarta: Salemba Empat.

Departemen Perdagangan Indonesia. Pengembangan Ekonomi Kreatif Indonesia 2009-2025.

Echdar, S. 2013. Manajemen Entrepreneurship: Kiat Sukses Menjadi Wirausaha. Yogyakarta: Andi.

Howkins, J. 2001. The Creative Economy: How People Make Money from Ideas. London: Penguins Books. 